Research Paper

\title{
Comparison of Power Consumption Efficiency of CVT and Multi- Speed Transmissions for Electric Vehicle
}

\author{
Jiageng Ruan ${ }^{1)}$ Paul Walker ${ }^{1)}$ Nong Zhang ${ }^{1)}$ \\ 1) University of Technology Sydney \\ 15 Broadway, Ultimo, New South Wales, Australia (Email:Jiageng.Ruan@uts.edu.au)
}

Received on June 23, 2017

\begin{abstract}
Due to the low energy density of electrochemical battery in Electric Vehicles (EVs), the driving range per charge has been limited. However, the widely adopted single reduction gear in EVs typically do not achieve the diverse range of functional needs. Consequently, multi-speed EV powertrains have been compared and investigated for these applications. Through the optimizing of gear ratios, a more diverse range of functional needs can be realized without increasing the practical size of the electric motor. This paper studies the performance improvements realized through utilization of 2-4 speeds and continuously variable transmission. Results demonstrate that there can be significant benefits attained for both small and large passenger vehicles.
\end{abstract}

\section{KEY WORDS: EV and HV Systems, Transmission, CVT [A3]}

\section{Introduction}

Despite long-term benefits of Battery Electric Vehicles (BEVs) to customers and environment, the initial cost and unsatisfactory driving range per charge present significant barriers for large-scale commercialization. Since a major breakthrough for battery technology in terms of specific energy, is not likely to occur in the coming few years, it is necessary to pursue every possible avenue to improve powertrain efficiency. Regenerative braking and multi-speed transmission are considered as the two most promising options to fill the gap between increasing driving capabilities and battery technology development.

The application of multi-speed transmissions to Electric Vehicle (EV) seeks to improve the operating efficiency of motor and enhance driving performance ${ }^{(1,2)}$. A infinitely variable transmission was proposed by Bottiglione to reduce energy consumption for EV (3). An optimized two-speed automatic transmission was integrated into an electric commercial van ${ }^{(4)}$ to improve dynamic and economic performance. The effects of adding a two-speed AMT to BEVs and a similar system was tested on a pure electric bus ${ }^{(5,6)}$. These make up a handful of the available literature that has evaluated the improved economy of adding multispeed transmissions to BEVs. Considering the main difficulties in achieving this are the development of very efficient transmission systems and integrating this design with the vehicle powertrain development, whilst simultaneously maintaining the smooth driving experience of $\mathrm{EV}$, a comparative study of energy consumption and costs of alternative BEV transmissions demonstrated that both twospeed DCT and simplified CVT can improve the overall powertrain efficiency, save battery energy and reduce customer costs ${ }^{(7)}$. Ren.et.al. ${ }^{(8)}$ showed a brief comparison of 1-4 speeds $\mathrm{EV}$, which adopted several subjective ratios and unrealistic shifting algorithm. In summary, the aforementioned studies analysed the complicated relationship of gear numbers design, gear ratios selection, shifting schedules design and related cost and benefits for BEVs. Specifically, following points were missing in the most of previous multi-speed BEV related papers: 1) structure analysis of selected transmission. 2) ratios design for multi-speed transmission on BEV based on the specified motor characteristics and target vehicle performance. 3) shifting schedules design based on selected gear ratios for various speeds BEV. 4) detailed comparison of potential cost (efficiency loss and weight increasing) and benefit (driving range extend and energy consumption reducing)

The purpose of this paper is to therefore present the findings of an evaluation study into the application of a number of variables associated with the development of modern electric vehicles. In addition to the comparison of the two alternative vehicle platforms, B-class and E-class, this paper will investigate a number of alternative considerations, including application of single and different multi-speed transmissions

The intention of this paper is to cover a wide range of configurations for BEVs considering transmission arrangements. To achieve this the remainder of the papers is divided into the following chapters: 1) the alternative transmission configurations are introduced and the impact of gear ratio selection is discussed, 2) the EV performance are summarized based on various powertrain architectures 3) the paper is summarized and conclusions are drawn based on the results.

\section{Alternative Transmission Configurations}

\subsection{Summary of Vehicle Configurations}

Simulations are carried out to compare the alternative platforms, this section summarizes the simulation parameters each configuration. For the purpose of this paper two extremes of vehicle class are evaluated. At the small end of the size spectrum there is the B-Class platform, often referred to as superminis. The large vehicle platform that will be studied in this paper is the executive sedan or E-Class vehicle. Vehicle characteristics are noted in the following sections. 


\section{B-Class EV configuration}

The B-class car covers the Supermini/Subcompact/City/Small car segment of the automotive passenger vehicle market. They comprise of approximately $30 \%$ of vehicle sales in Australia (FCIA 2014) ${ }^{(9)}$ depending on where the exact divisions are made between classes. It should be noted that the nominal vehicle mass is shown below, variations for additional transmission ratios in the summary, but are included in simulations.

\section{E-Class EV configuration}

The E-class car covers the Executive/Large/Full size car segment of automotive passenger vehicles. They comprise of approximately $6 \%$ of vehicle sales in Australia ${ }^{(9)}$. These are significantly larger than B-class vehicles and may represent the other end of passenger vehicle market in terms of vehicles size. Vehicles are summarized in Table.1.

Table 1: Vehicle specifications and target performance

\begin{tabular}{|c|c|c|c|c|}
\hline & B-Class & E-Class & Unit & Parameter \\
\hline Gross Weight & 1400 & 2200 & $\mathrm{~kg}$ & $\mathrm{~m}$ \\
\hline $\begin{array}{c}\text { Vehicle Front } \\
\text { Areas }\end{array}$ & 2.47 & 2.68 & $\mathrm{~m}^{2}$ & $\mathrm{~A}$ \\
\hline $\begin{array}{c}\text { Aero-drag } \\
\text { Coefficient }\end{array}$ & 0.28 & 0.3 & $/$ & $\mathrm{Cd}$ \\
\hline Tyre Radius & 0.302 & 0.344 & $\mathrm{~m}$ & $\mathrm{r}$ \\
\hline $\begin{array}{c}\text { Tyre Rolling } \\
\text { Coefficient }\end{array}$ & 0.013 & 0.013 & $/$ & $\mathrm{Ct}$ \\
\hline Air Density & 1.127 & 1.127 & $\mathrm{Kg} / \mathrm{m}^{3}$ & $\rho$ \\
\hline
\end{tabular}

\subsection{Single Speed EV}

Single speed EVs (Fig.1 (a)) is the convention in current market available EV, including the BMW i3, Mitsubishi iMIEV, Nissan Leaf and all Tesla models. Generally speaking, the reasoning behind this is a combination of the capability to meet a wide range of driving operating conditions using the electric machine and the desire for maximum powertrain efficiency. Depending on the motor design and the desired performance of the vehicle, the transmission will typically include one fixed ratio and one final drive gear ratio.

\subsection{Two, Three and Four Speeds EV}

A two-speed BEV, shown in Fig.1 (b), or even multi-speed BEVs, shown in Fig.1 (c, d), decouple the launch, top speed, and economic driving requirements for the vehicle from the motor speed and torque range through the application of multiple gear ratios that are likely to improve the overall operating performance of the vehicle. The benefits of using two or more speeds are:

1. Improved motor efficiency over the vehicle driving range

2. Decoupled top speed and acceleration capabilities

The disadvantages include:

1. Increased weight from additional components

2. Poorer transmission efficiency

3. Higher manufacturing costs a)

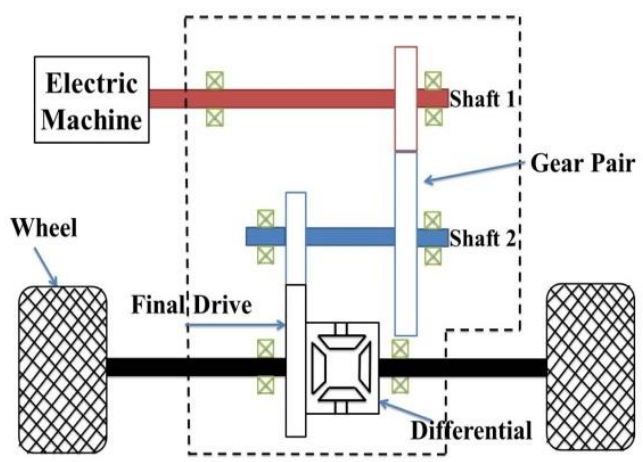

b)

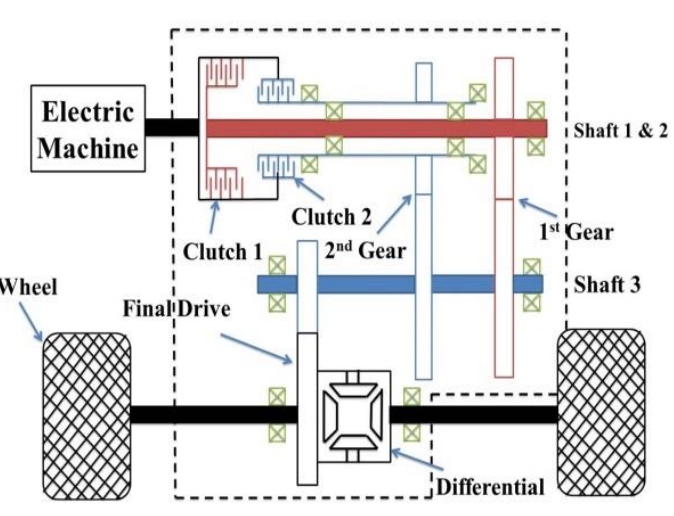

c)

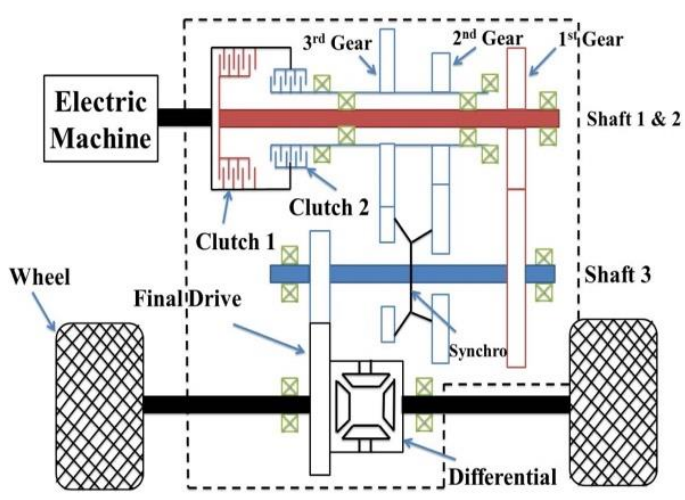

d)

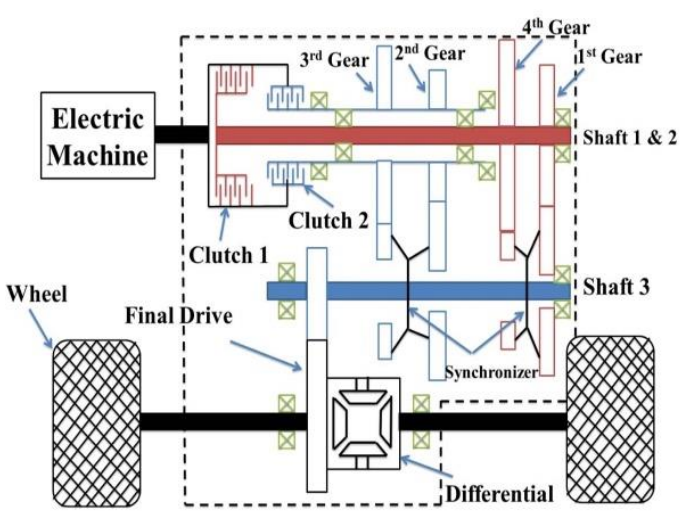

Fig.1: One-speed and /two/three/four-speed DCT electric vehicle schematic 
The two, three and four speeds transmissions include two sets of parallel gears coupled with a common clutch to the electric machine. The clutches are denoted with $\mathrm{C} 1$ and $\mathrm{C} 2$. For the two-speed transmission no synchroniser is used and shifting is performed between clutches with fixed ratios. For the three speed transmission a synchroniser pair is used for first and third gears to select alternative ratios, while the four-speed structure have two synchroniser pairs.

Whilst multi-speed transmissions allow for independent optimization of performance characteristics, the most significant impact is the application of multispeed transmissions increases the losses present through clutches, gear mesh and so on. Impact of efficiency can be viewed in terms of different components ${ }^{(10)}$, for the driveline there are several component losses that can be approximated for rapid assessment of variation of transmission loss:

- Differential 5\%

- Single gear ratio friction loss $1 \%$ (only the gear pair under load)

- Single gear ratio viscous loss $1 \%$ (each gear pair spinning in lubricant)

- Wet clutch losses 2 3\%

- Synchronizer mechanism 1 2\%

The implication of such estimation is the changing from a single to two speed design will increase losses by up to $4 \sim 5 \%$ (less if dry clutches are used) but further additions will only increase losses by $2 \sim 3 \%$ per gear. Furthermore, if electromechanical actuators are used then minimal parasitic losses for the transmission control unit will be incurred ${ }^{(11)}$. The overall efficiencies of multi-speed gearbox are summarised in the Table.2

Table 2: Multi-Speed dual clutch transmission efficiency

\begin{tabular}{|c|c|c|c|c|}
\hline Transmission Type & One-Speed & Two-Speed & Three-Speed & Four-Speed \\
\hline Overall Efficiency & 0.93 & 0.86 & 0.83 & 0.80 \\
\hline
\end{tabular}

\subsection{Continuously Variable Transmission based EV}

CVT has the ability to adjust gear ratios without interruption of the power flow and an infinite number of ratios are possible. The basic configuration of CVT comprises two variable diameter pulleys kept at a fixed distance apart and connected by a power-transmitting device, e.g. belt or chain. Due to the mechanical layout and the need of torque converter to work with ICE vehicles, the efficiency of CVT is relatively low, compared to other stepped transmissions. However, due to the advantage of excellent motor dynamic performance, e.g. $100 \%$ torque output ability from stall, accurate and fast adjusting ability and no limitation of minimum speed for steady running, torque converter is not necessary for EVs anymore. Furthermore, , the efficiency can be furtherly improved by using servo-electromechanical actuators to replace the moveable pulleys ${ }^{(12)}$. In this study, efficiency improved and structure simplified CVT is adopted and the schematic is presented in Fig.2:

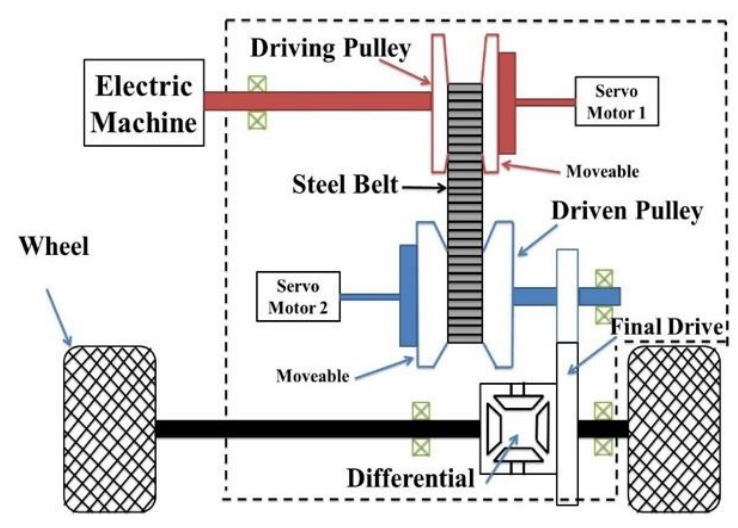

Fig.2: Continuously variable transmission with servoelectromechanical actuation system

\subsection{Motor power rating}

A vehicle's driving performance is usually evaluated by its acceleration time, top speed, and grade ability. In EV drivetrain design, proper motor power rating and transmission parameters are the primary considerations to meet the performance specification. The design of all these parameters depends mostly on the speed-power (torque) characteristics of the traction motor. This characteristic is represented by a speed ratio $\mathrm{x}$, also known as extended-speed range defined as the ratio of its maximum speed to its base speed.

For passenger cars, acceleration performance is more important than maximum cruising speed and grade ability, since it is the acceleration requirement rather than the maximum cruising speed or the gradeability that dictate the power rating of the motor drive. The total tractive power for accelerating the vehicle from zero to speed $V_{f}$ in $t_{a}=10$ seconds can be finally obtained as (Eq.4.12) ${ }^{(13)}$ :

$$
P_{t}=\frac{\left(V_{f}^{2}+V_{b}^{2}\right) \delta M}{2 t_{a}}+\frac{2 M g f_{r} V_{f}}{3}+\frac{\rho_{a} C_{D} A_{f} V_{f}^{3}}{5}
$$

$V_{b}$ is the initial velocity; $\delta M$ stands for equivalent mass including rotating parts; $g$ is the gravity acceleration; $f_{r}$ represents the coefficient of rolling resistance; $\rho_{\mathrm{a}}$ is air density; $C_{D}$ represents aerodynamic drag coefficient; $A_{f}$ is vehicle frontal area. Substituting the specifications of B-class and E-class EV in Table.1 to Eq. (1), the required motor rating power, to accelerate the vehicle from 0 to $100 \mathrm{~km} / \mathrm{h}$, are estimated to be around $\mathrm{P}_{\mathrm{t}_{\mathrm{B}} \mathrm{B}}=59 \mathrm{kw}$ and $\mathrm{P}_{\mathrm{t}_{-} \mathrm{E}}=111 \mathrm{kw}$ respectively.

Although a greater speed ratio will significantly lower the motor power rating requirement and improve vehicular dynamic performance ${ }^{(14,15)}$, especially for initial accelerating, they are set 2.5 and 3 respectively ${ }^{(13,16,17)}$ for selected motors (Table.3) in this study to achieve a trade-off of vehicular dynamic performance and motor shape, which is mainly determined by motor type and control strategy. 
Table 3: Selected motor specifications of B and E-Class EV

\begin{tabular}{|c|c|c|}
\hline Parameters & B-Class & E-Class \\
\hline Motor Type & Permanent Magnetic AC & Permanent Magnetic AC \\
\hline Peak Power (kw) & 65 & 110 \\
\hline Max Torque (Nm) & 250 & 350 \\
\hline Max Speed (rpm) & 6250 & 9000 \\
\hline Base Speed (rpm) & 2500 & 3000 \\
\hline $\begin{array}{l}\text { Speed Ratio (Max/Base } \\
\text { Speed) }\end{array}$ & 2.5 & 3 \\
\hline
\end{tabular}

\subsection{Transmission Ratio Design}

\section{Maximum ratio}

The greatest traction requirement must be known to determine the ratio of the gear with the largest torque multiplication. The capability to climb inclines is important for entering and leaving steep driveways and parking structures. The largest overall gear ratio required for the powertrain is set based on this need for passenger vehicles, it uses the ratio of rolling resistance and incline load for a specified grade divided by the maximum motor torque multiplied by the overall powertrain efficiency, given in Eq. (2). For low speeds the aerodynamic drag is assumed to be zero.

$$
\gamma_{\text {Max }}=r_{t} M_{v} g\left(C_{R} \cos \varphi+\sin \varphi\right) /\left(T_{E M} \eta_{P T}\right)
$$

$\gamma$ is the gear ratio. A climbing performance of $\varphi_{\max }$ greater than $50 \%$ is normally required for an unloaded passenger car. This ensures that a trailer can be towed and steep ramps overcome with ease (18).

\section{Minimum ratio}

Vehicle top speed varies significantly depending on application and is reasonably important for consumer acceptance. The maximum speed achieved in the vehicle can then be used to determine the lowest possible ratio. It must consider the motor characteristics in terms of maximum rotating speed $(\mathrm{rad} / \mathrm{s})$ and the ability of the motor torque to reach this top speed $(\mathrm{km} / \mathrm{h})$. A ratio lower than the value, which is defined by the maximum motor speed, converted to $\mathrm{km} / \mathrm{h}$ divided by the maximum vehicle speed, is necessary:

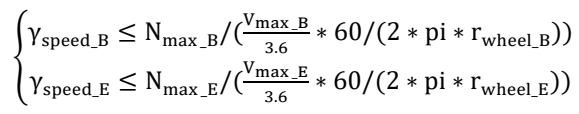

This ratio can be checked against the capability of the motor to supply torque at this speed by dividing the rolling resistance and aerodynamic drag by the maximum motor torque at its maximum speed.

$$
\gamma_{\text {min,torque }} \geq r_{t}\left(C_{R} M_{v} g \cos \varphi+M_{v} g \sin \varphi+C_{D} \rho A_{V} V^{2}\right) /\left(\eta_{P T} T_{@ \operatorname{maxRPM}}\right)
$$

Substitute vehicle specifications of Table.1 to Eqs. (2-4), the gear ratio range of B-Class and E-Class vehicle can be determined as:

$$
\begin{gathered}
\text { B-Class: }\left\{\begin{array}{c}
\gamma_{\text {Max }} \geq 9.5 \\
\gamma_{\text {min,speed }} \leq 5.1 \\
\gamma_{\text {min,torque }} \geq 2.6
\end{array}\right. \\
\text { E-Class: }\left\{\begin{array}{c}
\gamma_{\text {Max }} \geq 11.3 \\
\gamma_{\text {min,speed }} \leq 5.4 \\
\gamma_{\text {min,torque }} \geq 4.5
\end{array}\right.
\end{gathered}
$$

The ratio requirement for top speed is in conflict with that for grade in single speed ratio design, which means an inevitable dynamic performance trade-off for single speed transmission. There is no doubt that both of speed and grade requirements can be covered though applying a more powerful motor. However, it will significantly increase the powertrain cost. One of the primary goals in this study is evaluating whether the combination of multi-speed transmission and related motor can achieve a similar or better performance, comparing to the available EVs on the market, in terms of cost/performance. Therefore, the ratios of single speed transmission is set to cover the speed limit of most countries around the world (19), meanwhile, providing torque as much as possible:

$$
\gamma_{B}=\gamma_{E}=8
$$

For a two-speed DCT, $1^{\text {st }}$ gear is selected for accelerating and climbing, meets requirement in Eq. (2). The $2^{\text {nd }}$ gear is used to cruise at high speed, meeting requirement in equation Eqs. (3) and (4). A greater $2^{\text {nd }}$ ratio and a lower $1^{\text {st }}$ ratio will prevent motor operating at extreme conditions, e.g. maximum torque output, maximum speed output, and help motor achieve a higher average efficiency:

$$
\begin{gathered}
\text { B-Class: }\left\{\begin{array}{l}
\gamma_{\mathrm{B}_{\max }}=11 \\
\gamma_{\mathrm{B}_{\min }}=4
\end{array}\right. \\
\text { E-Class: }\left\{\begin{array}{c}
\gamma_{\mathrm{E}_{\max }}=12 \\
\gamma_{\mathrm{E}_{\min }}=5
\end{array}\right.
\end{gathered}
$$

Selection of intermediate gear ratio for three and four speeds EV

There are two generally accepted methods for determining intermediate gear ratios, i.e. the geometric and progressive methods ${ }^{(20,21)}$. From these methods it will be possible to determine some available options for the selection of the intermediate ratio of the three and four speeds transmission.

Geometric design of intermediate ratios has the advantage of utilising the motor at similar operating speeds across the vast majority of driving speeds for the vehicle. Therefore, the minimum and maximum motor speeds for each ratio is identical. However, this method for selection is generally applied to heavy vehicles rather than passenger vehicles to ensure the prime mover operates in a specific speed range for most driving conditions.

Progressive ratio design is where the span of vehicle speed between gear changes is kept constant. The ratio $i_{n}$ is the gears $\mathrm{n}=1$ to $\mathrm{z}$ are found to be:

$$
\mathrm{i}_{\mathrm{n}}=\mathrm{i}_{\mathrm{z}} \varphi_{1}{ }^{(\mathrm{z}-\mathrm{n})} \varphi_{2}{ }^{0.5(\mathrm{z}-\mathrm{n})(\mathrm{z}-\mathrm{n}-1)}
$$

$\varphi_{1}$ is the ratio gap of neighbour gears, $\varphi_{2}$ is the selected progression factor, $z$ is the total gear number. Normally, $1.1<\varphi_{1}<1.7,1.0<\varphi_{2}<1.2^{(20)}$. The base ratio change $\varphi_{1}$ can be calculated as:

$$
\varphi_{1}=\sqrt[z-1]{\frac{1}{\varphi_{2}^{0.5(z-n)(z-n-1)}} i_{G, \text { total }}}
$$


The overall gear ratio, $i_{G, \text { total }}$, of the transmission, also known as the range of ratios, is the ratio between the largest and smallest ratio:

$$
\mathrm{i}_{\mathrm{G}, \text { total }}=\frac{\mathrm{i}_{\mathrm{g}, \max }}{\mathrm{i}_{\mathrm{g} \text {,min }}}=\frac{\mathrm{i}_{1}}{\mathrm{i}_{\mathrm{z}}}
$$

Substituting Eq. (8) and Eq. (9) to Eqs. (10-12), the intermediate gear ratio for three-speed EV can be obtained as

$$
\mathrm{i}_{2_{\mathrm{B}}}=6.6, \mathrm{i}_{2_{\mathrm{E}}}=7.7
$$

For four-speed EV:

$$
\left\{\begin{array}{l}
\mathrm{i}_{2_{B}}=8.1, \mathrm{i}_{3_{B}}=5.6 \\
\mathrm{i}_{2_{\mathrm{E}}}=9.3, \mathrm{i}_{3_{\mathrm{E}}}=6.7
\end{array}\right.
$$

Considering the most common BEV driving type is frontmounted-front-drive and the characteristics of motor in Table.1, the final drive ratio is set as 4 for both B-Class and E-Class ${ }^{(20)}$. The following table lists all the ratios of single speed, two/three/four speeds DCT (Incl. final drive):

\begin{tabular}{|c|c|c|c|c|}
\hline Single Speed & $\begin{array}{c}\text { Two-speed } \\
\text { DCT }\end{array}$ & $\begin{array}{c}\text { Three-speed } \\
\text { DCT }\end{array}$ & $\begin{array}{c}\text { Four-speed } \\
\text { DCT }\end{array}$ & CVT \\
\hline $\begin{array}{c}\text { Transmission } \\
\text { Ratio: } \\
2 \text { (2) }\end{array}$ & $\begin{array}{l}\text { Transmission } \\
\text { Ratio: } \\
1^{\text {st: } 2.75 ~(3) ~}\end{array}$ & $\begin{array}{l}\text { Transmission } \\
\text { Ratio: } \\
1^{\text {st: } 2.75 ~(3) ~}\end{array}$ & $\begin{array}{l}\text { Transmission } \\
\text { Ratio: } \\
1^{\text {st: }: 2.75(3)}\end{array}$ & $\begin{array}{c}\text { Transmission } \\
\text { Ratio: } \\
0.6^{\sim} 2.45\end{array}$ \\
\hline $\begin{array}{l}\text { Final Ratio: } \\
\qquad 4(4)\end{array}$ & $\begin{array}{c}2^{\text {nd: }} 1(1.25) \\
\text { Final Ratio: } \\
\quad 4(4)\end{array}$ & $\begin{array}{c}2^{\text {nd }}: 1.65 \\
\quad(1.59) \\
3^{\text {rd }}: 1(1.25) \\
\text { Final Ratio: } \\
\quad 4(4)\end{array}$ & $\begin{array}{c}2^{\text {nd }}: 2.03 \\
(2.33) \\
3^{\text {rd }}: 1.4(1.68) \\
4^{\text {th }}: 1(1.25) \\
\text { Final Ratio: } \\
4(4)\end{array}$ & $\begin{array}{c}\text { Final Ratio: } \\
5\end{array}$ \\
\hline
\end{tabular}

Table 4: Gear ratios of transmission systems for B-Class (EClass) vehicle

To make this paper in an appropriate length, only full simulations are presented for B Class EV in the following sections, the results of all other simulations are summarized in table forms.

\subsection{Shifting schedule}

The gear shifting schedules of two, three and four speeds DCT, shown in Fig.5, are based on a previous paper (7) that utilizes the mapped efficiency of the electric machine to maximize the driving efficiency of the powertrain depending on the selected gear ratio. It is worth noting that the vertical part of each shifting curve is the result of speed limitation by certain gear ratio.

The ratios of CVT can vary continuously, thus, an infinite number of gear ratios are available between the limitations. For certain vehicle speed and throttle pedal position, the motor speed can continuously vary, according to the selected gear ratio in shifting schedule. Therefore, the most economic gear ratio at particular vehicle speed and throttle position can be determined, by comparing the motor efficiency at such speed with different gear ratio. By this analogy, all the economy performance oriented shifting point at particular speed and throttle position can be achieved as shown in Fig.3(d). The step length of selecting points in available gear ratio coverage is 0.1 .

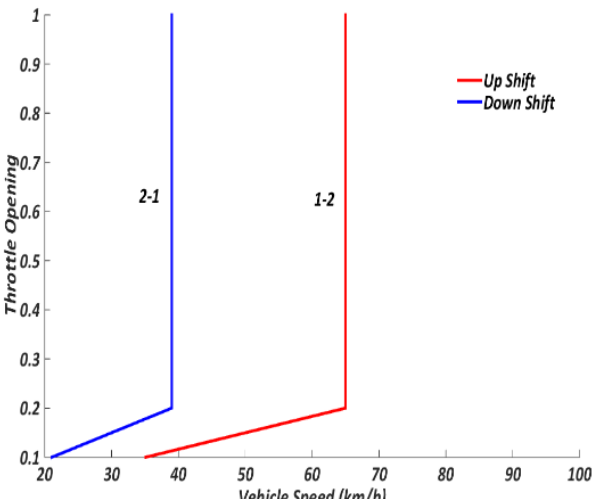

a)

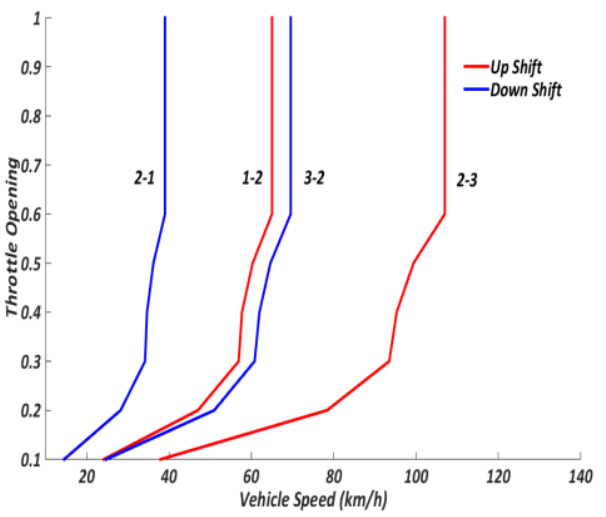

c)
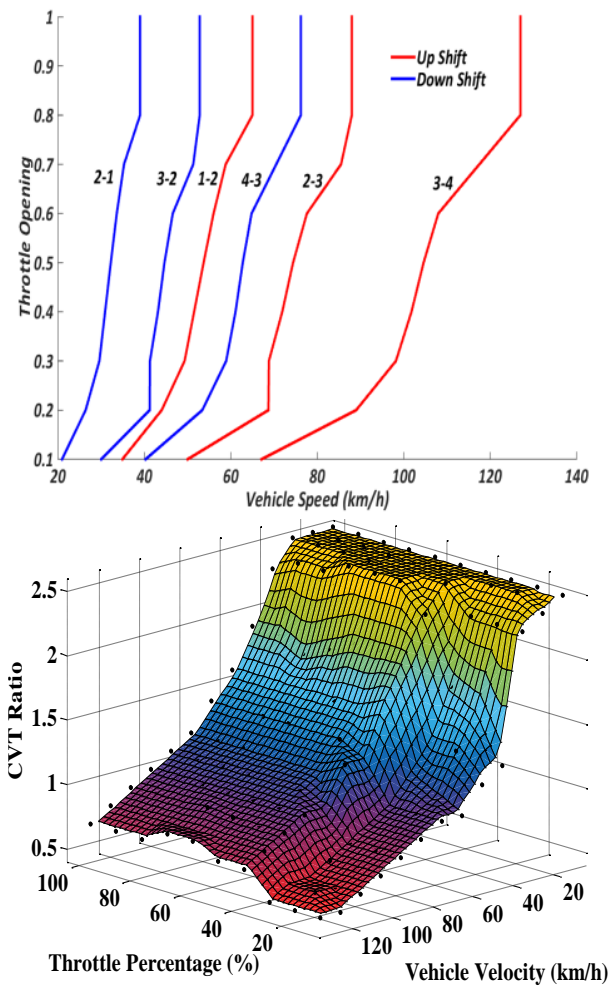

d)

Fig.3: Shifting Schedules of B-Class EV, (a) Two-speed shifting schedule (b) Three-speed shifting schedule (c) Four-speed shifting schedule (d) CVT shifting strategy 


\section{Electric vehicle with multi-speed transmission}

Analysing will be based on a combined fuel economy testing cycle, which is calculated by averaging the city and highway (FTP75 and HWFET) fuel economies with weightings of 55 per cent and 45 per cent, respectively, through Eq. (15). An approximation of the 5-cycle fuel economy values can be calculated directly from the "unadjusted" FTP75 and HWFET fuel economy values by Eqs. (16) and (17) ${ }^{(22)}$.

$$
\begin{gathered}
\text { Combine }_{\mathrm{KPK}}=\frac{1}{\left(\frac{0.43}{[5-\text { cycke City } \mathrm{KPK}]}+\frac{1}{[5-\text { cycke Highway } \mathrm{KPK}]}\right)} \\
\text { Highway }_{\mathrm{KPK}}=\frac{1}{\left(0.001376+\frac{1.3466}{\mathrm{HWFET}_{\mathrm{KPK}}}\right)} \\
\text { City }_{\mathrm{KPK}}=\frac{1}{\left(0.003259+\frac{1.1805}{\mathrm{FET}_{\mathrm{KPK}}}\right)}
\end{gathered}
$$

KPK is the abbreviation of $\mathrm{kWh}$ per kilometre. Substitute simulation results into Eqs. (15-17), the consumed electricity of $\mathrm{BEV}$ with various gear number in cycles are summarized in the Table.5.

The current average driving range per driver per day is between 40-50km in US, UK, Australia, Singapore and China major cities ${ }^{(23-28)}$. However, this range is far more away from the requirement of average daily driving mileage for home-use personal vehicle. A short trip capability for EV is still an important factor for potential customers' willingness of purchasing. According to the study ${ }^{(29)}$, the percentage of days in a whole year, when daily driving range does not exceeds 160 $\mathrm{km}$, is over $95 \%$. Considering a $32 \mathrm{~km}$ 'range buffer' for passenger vehicle ${ }^{(29)}, 200 \mathrm{~km}$ one-charge range is regarded as an appropriate range for most consumers who would charge once per day only, typically at home over night.

Table 5: Consumed electricity per 100km of B-Class BEVs

\begin{tabular}{|c|c|c|c|c|c|}
\hline $\mathrm{kWh} / 100 \mathrm{~km}$ & $\begin{array}{c}\text { One- } \\
\text { speed }\end{array}$ & $\begin{array}{c}\text { Two- } \\
\text { speed }\end{array}$ & $\begin{array}{c}\text { Three- } \\
\text { speed }\end{array}$ & $\begin{array}{c}\text { Four- } \\
\text { speed }\end{array}$ & $\mathrm{CVT}$ \\
\hline City & 10.3 & 9.04 & 8.74 & 9.10 & 7.02 \\
\hline Highway & 11.6 & 9.4 & 9.1 & 8.9 & 8.07 \\
\hline Combined Cycle & 11.0 & 9.2 & 8.9 & 9.0 & 7.6 \\
\hline $\begin{array}{c}\text { Energy Utilizing } \\
\text { Rate Improvement }\end{array}$ & 0 & $+16.4 \%$ & $+19.7 \%$ & $+18.6 \%$ & $+31 \%$ \\
\hline $\begin{array}{c}\text { Required battery } \\
\text { capacity for 200km } \\
\text { range* }\end{array}$ & $28 \mathrm{kWh}$ & $23 \mathrm{kWh}$ & $23 \mathrm{kWh}$ & $23 \mathrm{kWh}$ & $\begin{array}{c}18 \\
\mathrm{kWh}\end{array}$ \\
\hline
\end{tabular}

Table 6: Consumed electricity per 100km of E-Class BEVs

\begin{tabular}{|c|c|c|c|c|c|}
\hline $\mathrm{kWh} / 100 \mathrm{~km}$ & $\begin{array}{c}\text { One- } \\
\text { speed }\end{array}$ & $\begin{array}{c}\text { Two- } \\
\text { speed }\end{array}$ & $\begin{array}{c}\text { Three- } \\
\text { speed }\end{array}$ & $\begin{array}{c}\text { Four- } \\
\text { speed }\end{array}$ & CVT \\
\hline City & 18.8 & 17.0 & 17.1 & 16.0 & 13.2 \\
\hline Highway & 17.1 & 15.5 & 15.6 & 14.5 & 14.1 \\
\hline Combined Cycle & 17.8 & 16.1 & 16.2 & 15.1 & 13.6 \\
\hline $\begin{array}{c}\text { Energy Utilizing } \\
\text { Rate Improvement }\end{array}$ & 0 & $9.6 \%$ & $9.0 \%$ & $15.8 \%$ & $24 \%$ \\
\hline $\begin{array}{c}\text { Required battery } \\
\text { capacity for 200km } \\
\text { range* }\end{array}$ & $45 \mathrm{kWh}$ & $41 \mathrm{kWh}$ & $41 \mathrm{kWh}$ & $38 \mathrm{kWh}$ & $\begin{array}{c}34 \\
\mathrm{kWh}\end{array}$ \\
\hline
\end{tabular}

* The actual operating life of the battery is affected by the charging and discharging rates, Depth of Discharge (DOD), and other conditions such as temperature. Additionally, a normal $80 \%$ DOD is preferred in automobile application to effectively extend battery life cycle. Therefore, a $20 \%$ battery capacity design redundancy is included in this study. The required battery capacity, consequently, can be achieved.
As shown in above tables, comparing to fixed ratio one gear $\mathrm{BEV}$, one additional gear significantly improve energy utilizing efficiency by $16.4 \%$ in B-Class and $9.6 \%$ in E-Class respectively. Specifically, another gear does continuously improve the efficiency of B-Class BEV, but not as much as the first added one due to the increased energy loss in transmission. When the gear number goes to four, saved energy by increasing motor efficiency cannot cover the loss in transmission leading to a decreased energy-utilizing rate, comparing 3-speed B-Class $\mathrm{BEV}$. The circumstance is different for E-Class BEV, the 3speed transmission does not show the benefit as it does in BClass BEV. On the contrary, a slight energy efficiency drop is recorded comparing to 2-speed powertrain. However, one more gear makes the 4-speed DCT competitive to 2-speed one in term of energy utilizing rate in E-Class BEV.

Figures 4 and 5 demonstrate the motor operating tracks of B-class EV in city and highway driving cycles. It is clear that single speed transmission based motor, due to the trade-off ratio design, has to frequently work in relatively low efficiency area, where is in the high speed \& low torque, or high torque \& low speed zone. In addition, thanks to the infinite and continuously varying ratios, CVT help motor to gain the highest efficiency during both cycles

In terms of the multi-speed stepped transmissions, with the help of wider gear ranges and intermedia gear, operating tracks move to more efficient regions. However, there is no significant difference can be found between 2, 3 and 4 speeds architectures.

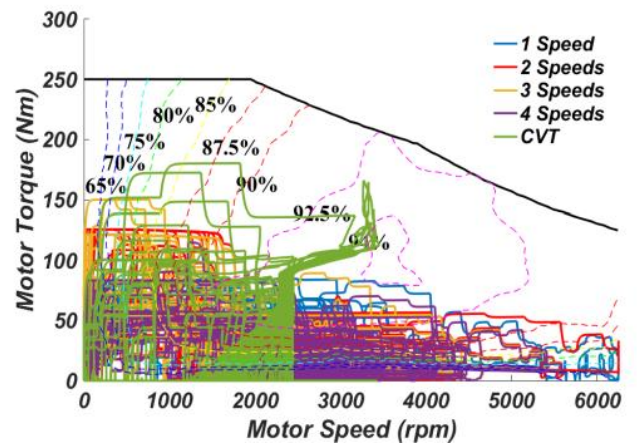

Fig.4: Motor operating tracks in FTP75 of B-Class BEV

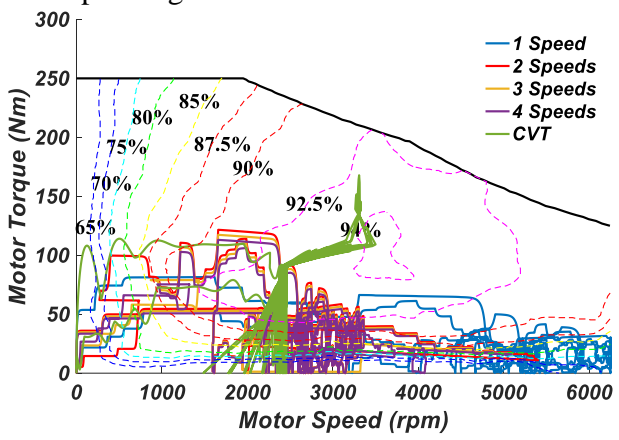

Fig.5: Motor operating tracks in HWFET of B-Class BEV

Another significant benefit of multi-speed transmission based BEV is the reduction of battery size. One more gear, compared to single speed, can reduce $4-5 \mathrm{kWh}$ battery capacity requirements. Increasing speeds to three and four does not save 
much more cost on battery. The increased cost of multi-speed transmissions is taken into consideration in the following section to investigate if the benefits from battery reduction will be offset. It seems necessary to add the $4^{\text {th }}$ gear to E-Class BEV.

According to the method of "design using characteristic value" ${ }^{(30)}$, the transmission relative selling price (RSP) can be related to the input torque $T_{1}$, the maximum ratio $i_{G, \max }$, and the number of gears $z$, shown in Eq. (18).

$$
\mathrm{RSP}=0.0183 \times\left(\mathrm{i}_{\mathrm{G}, \max } \times \mathrm{T}_{1}\right)^{0.512} \mathrm{z}^{0.256}
$$

Based on the data in Table. 3 and Table.4, the estimated gearbox relative selling prices (RSP) are presented in Table.7. However, a one-speed transmission is more similar to the main reducer, or final drive ratio, in multi-speed transmissions rather an actual transmission. The estimated price for a one-speed transmission using RSP is unrealistic. Therefore, its price is reduced to zero in this study by assuming that the final drive gear is common to all configurations. Allowing evaluation of the multi-speed transmissions capacity to compensate for the cost of the transmission through savings realised in battery energy storage and component manufacturing costs.

Table 7: Estimated gearboxes relative selling price

\begin{tabular}{|c|c|c|c|c|c|c|}
\hline Type & $\begin{array}{c}T_{1}=350 \mathrm{Nm}, \\
z=6, i_{G, \max } \\
=5.5\end{array}$ & $\begin{array}{c}\text { One- } \\
\text { speed }\end{array}$ & $\begin{array}{c}\text { Two- } \\
\text { speed }\end{array}$ & $\begin{array}{c}\text { Three- } \\
\text { speed }\end{array}$ & $\begin{array}{c}\text { Four- } \\
\text { speed }\end{array}$ & $\begin{array}{c}\text { CVT } \\
\text { (=6 } \\
\text { speeds) }\end{array}$ \\
\hline $\begin{array}{c}\text { RSP (B- } \\
\text { Class) }\end{array}$ & 1 & 0.52 & 0.62 & 0.69 & 0.74 & 0.86 \\
\hline $\begin{array}{c}\text { Increased } \\
\text { Cost } \\
\text { Comparing } \\
\text { to Single } \\
\text { Speed (B- } \\
\text { Class) }\end{array}$ & N/A & 0 & $\begin{array}{c}+ \\
62 \%\end{array}$ & $\begin{array}{c}++ \\
11 \%\end{array}$ & $\begin{array}{c}+++ \\
7 \%\end{array}$ & $\begin{array}{c}+++ \\
16 \%\end{array}$ \\
\hline $\begin{array}{c}\text { RSP (E- } \\
\text { Class) }\end{array}$ & 1 & 0.64 & 0.77 & 0.85 & 0.92 & 1.08 \\
\hline $\begin{array}{c}\text { Increased } \\
\text { Cost } \\
\text { Comparing } \\
\text { to Single } \\
\text { Speed (E- } \\
\text { Class) }\end{array}$ & N/A & 0 & $\begin{array}{c}+ \\
+1\end{array}$ & $\begin{array}{c}++ \\
10 \%\end{array}$ & $\begin{array}{c}+++ \\
8 \%\end{array}$ & $\begin{array}{c}+++ \\
17 \%\end{array}$ \\
\hline
\end{tabular}

According to study ${ }^{(31)}$, the saved cost on electricity and battery manufacturing and increased cost on transmission are shown in Table.8, which are based on the assumption of $250,000 \mathrm{~km}$ vehicle lifespan, vehicle components price ${ }^{(32)}$ and performance in Table.9.

Table 8: Cost saves in electricity and battery components manufacturing for B-Class BEV

\begin{tabular}{|c|c|c|c|c|c|}
\hline & $\begin{array}{c}\text { One- } \\
\text { speed }\end{array}$ & $\begin{array}{c}\text { Two- } \\
\text { speed }\end{array}$ & $\begin{array}{c}\text { Three- } \\
\text { speed }\end{array}$ & $\begin{array}{c}\text { Four- } \\
\text { speed }\end{array}$ & CVT \\
\hline $\begin{array}{c}\text { Battery } \\
\text { components }\end{array}$ & 0 & $\begin{array}{c}-4000 \\
\text { (USD) }\end{array}$ & $\begin{array}{c}-4000 \\
\text { (USD) }\end{array}$ & $\begin{array}{c}-4000 \\
\text { (USD) }\end{array}$ & $\begin{array}{c}-8000 \\
\text { (USD) }\end{array}$ \\
\hline $\begin{array}{c}\text { Electricity for } \\
250000 \mathrm{~km} *\end{array}$ & 0 & $\begin{array}{c}-1666 \\
\text { (USD) }\end{array}$ & $\begin{array}{c}-1944 \\
\text { (USD) }\end{array}$ & $\begin{array}{c}-1852 \\
\text { (USD) }\end{array}$ & $\begin{array}{c}-2550 \\
\text { (USD) }\end{array}$ \\
\hline Transmission & 0 & $\begin{array}{c}+595 \\
\text { (USD) }\end{array}$ & $\begin{array}{c}+660 \\
\text { (USD) }\end{array}$ & $\begin{array}{c}+707 \\
\text { (USD) }\end{array}$ & $\begin{array}{c}+822 \\
\text { (USD) }\end{array}$ \\
\hline $\begin{array}{c}\text { Total cost save by } \\
\text { additional gears }\end{array}$ & 0 & $\begin{array}{c}-5099 \\
\text { (USD) }\end{array}$ & $\begin{array}{c}-5284 \\
\text { (USD) }\end{array}$ & $\begin{array}{c}-5145 \\
\text { (USD) }\end{array}$ & $\begin{array}{c}-9728 \\
\text { (USD) }\end{array}$ \\
\hline
\end{tabular}

Table 9: Cost saves in electricity and battery components manufacturing for E-Class BEV

\begin{tabular}{|c|c|c|c|c|c|}
\hline & $\begin{array}{c}\text { One- } \\
\text { speed }\end{array}$ & $\begin{array}{c}\text { Two- } \\
\text { speed }\end{array}$ & $\begin{array}{c}\text { Three- } \\
\text { speed }\end{array}$ & $\begin{array}{c}\text { Four- } \\
\text { speed }\end{array}$ & CVT \\
\hline $\begin{array}{c}\text { Battery } \\
\text { components }\end{array}$ & 0 & $\begin{array}{c}-3200 \\
\text { (USD) }\end{array}$ & $\begin{array}{c}-3200 \\
\text { (USD) }\end{array}$ & $\begin{array}{c}-5600 \\
\text { (USD) }\end{array}$ & $\begin{array}{c}-11000 \\
\text { (USD) }\end{array}$ \\
\hline $\begin{array}{c}\text { Electricity for } \\
250000 \mathrm{~km} *\end{array}$ & 0 & $\begin{array}{c}-1574 \\
\text { (USD) }\end{array}$ & $\begin{array}{c}-1481 \\
\text { (USD) }\end{array}$ & $\begin{array}{c}-2500 \\
\text { (USD) }\end{array}$ & $\begin{array}{c}-3150 \\
\text { (USD) }\end{array}$ \\
\hline Transmission & 0 & $\begin{array}{c}+959 \\
\text { (USD) }\end{array}$ & $\begin{array}{c}+1055 \\
\text { (USD) }\end{array}$ & $\begin{array}{c}+1139 \\
\text { (USD) }\end{array}$ & $\begin{array}{c}+1333 \\
\text { (USD) }\end{array}$ \\
\hline $\begin{array}{c}\text { Total cost save } \\
\text { by additional } \\
\text { gears }\end{array}$ & 0 & $\begin{array}{c}-3815 \\
\text { (USD) }\end{array}$ & $\begin{array}{c}-3626 \\
\text { (USD) }\end{array}$ & $\begin{array}{c}-6961 \\
\text { (USD) }\end{array}$ & $\begin{array}{c}-12817 \\
\text { (USD) }\end{array}$ \\
\hline
\end{tabular}

*The charging efficiency with Level 2 standard voltage is $81 \%{ }^{(33)}$, as a result of same $90 \%$ efficiency for both plug-in charger and lithium-ion battery charge/discharge ${ }^{(34)}$.

\section{Conclusion}

This study reports the application of alternative multispeed DCTs to traditional single reduction BEVs, comparing a range of vehicle and transmission configurations. The mechanism and structure of four transmissions are compared to demonstrate the advantages and disadvantages in manufacturing complexity, efficiency and cost. Following this the appropriate motor power is determined for B-Class and E-Class vehicles respectively by target acceleration time. Based on vehicle dynamic performance target and other widely accepted methods, such as climbing ability, top speed cruising and progressive ratio design algorithm, gear ratios of 2, 3, 4 speeds and continuously variable transmission are determined, and customized shifting schedules are designed for each transmission.

A comparison is carried out among alternative multi-speed powertrains in a hybrid cycle, which combines city cycle, FTP75, and highway cycle, HWFET, with weighting factors. The results demonstrate that the most remarkable and promising alternative transmission for EV is CVT. It shows the greatest potential and ability to reduce fuel consumption and manufacturing cost. Regarding the stepped transmission, 2speed DCT obtains the most remarkable energy utilizing rates improvement in both B-Class and E-Class BEVs, which are $16.4 \%$ and $9.6 \%$ higher than the single speed BEV respectively. Unlike the 3-speed DCT achieve a further efficiency improvement in B-Class BEV, it unexpectedly reduces the overall powertrain efficiency in E-Class BEV. Four-speed transmission helps E-Class BEV perform better, but it is not competitive to 2-speed one in term of energy utilizing rate in BClass BEV.

This paper is written based on a proceeding presented at JSAE 2017 Annual Congress

\section{Reference}

(1) Roberts, S. Multispeed transmission for electric vehicles. ATZ Worldw. Vol.114, Issue 4, pp 8-11 (2012).doi: 10.1007/s38311-012-0162-4 
(2) Di Nicola, F., Sorniotti, A., Holdstock, T., Viotto, F. \& Bertolotto, S. Optimization of a multiple-mpeed transmission for downsizing the motor of a fully electric vehicle. SAE Int. J. Alt. Power. SAE Paper 2012-01-0630 (2012) 2012;1:134-43. doi:10.4271/2012-01-0630.

(3) Bottiglione, F., De Pinto, S., Mantriota, G. \& Sorniotti, A. Energy consumption of a battery electric vehicle with infinitely variable transmission. Energies, Vol 7, pp.8317-8337 (2014).

(4) Morozov A, Humphries K, Zou T, Martins S, Angeles J. Design and Optimization of a Drivetrain with Two-speed Transmission for Electric Delivery Step Van. IEEE Int. Electr. Veh. Proceedings of . IEVC 2014, p.1-8 (2014) Florence, Italy (5) Wu G, Zhang X, Dong Z. Impacts of Two-Speed Gearbox on Electric Vehicle's Fuel Economy and Performance 2013, SAE Paper 2013-01-0349 (2013). doi:10.4271/2013-010349 .

(6) Jun-Qiang X, Guang-Ming X, Yan Z. Application of automatic manual transmission technology in pure electric bus. 2008 IEEE Veh Power Propuls Conf VPPC 2008, pp.5-8.(2008) doi:10.1109/VPPC.2008.46775837.

(7) Ruan, J., Walker, P. \& Zhang, N. A comparative study energy consumption and costs of battery electric vehicle transmissions. Appl. Energy Vol.165, pp.119-134 (2016).

(8) Ren, Q., Crolla, D. a. \& Morris, a. Effect of transmission design on Electric Vehicle (EV) performance. 2009 IEEE Vehicle Power and Propulsion Conference,

Dearborn, MI, 2009, pp. 1260-1265 (2009).

(9) Federal Chamber of Automotive Industries, http://www.fcai.com.au/sales (Accessed 15.07.2018),

(10) Zhou X, Walker P, Zhang N, Zhu B, Ruan J. Numerical and experimental investigation of drag torque in a two-speed dual clutch transmission. Mech Mach Theory, Vol.79, pp.46-63 (2014). doi:10.1016/j.mechmachtheory.2014.04.007.

(11) Berger, R., Meinhard, R. \& Bünder, C. The Parallel Shift Gearbox PSG. 7TH Luk Synposium (2002). doi:10.1017/CBO9781107415324.004

(12) Veenhuizen P a, Bonsen B, Klaassen TWGL, Albers PHWM. Pushbelt CVT efficiency improvement potential of servo-electromechanical actuation and slip control, p.1-7 (2004). (13) Mehrdad Ehsani, Yimin Gao, Ali, E. Modern electric, hybrid electric and fuel cell vehicles: fundamentals, theory, and design. CRC Press (2009).

(14) Ehsani M, Rahman KM, Toliyat HA. Propulsion system design of electric and hybrid vehicles. IEEE Trans Ind Electron, Vol.44, p.19-27 (1997) . doi:10.1109/41.557495.

(15) Rahman Z, Ehsani M, Butler K. An investigation of electric motor drive characteristics for $\mathrm{EV}$ and $\mathrm{HEV}$ propulsion systems, SAE Paper 2000-01-3062 (2000). doi:10.4271/200001-3062.

(16) Rahman Z, Butler K, Ehsani M. Effect of extendedspeed, constant-power operation of electric drives on the design and performance of EV-HEV propulsion system. SAE Paper 2000-01-1557 (2000). doi:10.4271/2000-01-1557.

(17) Zhu, Z. Q. \& Howe, D. Electrical Machines and Drives for Electric, Hybrid, and Fuel Cell Vehicles. Proc. IEEE Vol.95,pp. 746-765 (2007).

(18) Naunheimer, H., Bertsche;, B., Ryborz;, J. \& Novak, W. Automotive Transmissions Fundamentals, Selection, Design and Application. (Springer Berlin Heidelberg, 2011). doi:10.1007/978-3-642-16214-5

(19) Speed limits by country. Wikipedia n.d. https://en.wikipedia.org/wiki/Speed_limits_by_country(Accesse d 15.07.2018 )
(20) Naunheimer, H., Bertsche, B., Ryborz, J., Novak, W. Automotive Transmissions - Fundamentals, Selection, Design and Application | Springer. (2011).

(21) Walker PD, Roser H, Zhang N, Fang Y. Comparison of Powertrain System Configurations for Electric Passenger Vehicles, SAE Paper 2015-01-0052 (2015). doi:10.4271/201501-0052.

(22) Berry, I. M. The effects of driving style and vehicle performance on the real world fuel consumption of US light duty vehicles. (Massachusetts Institute of Technology, 2010).

(23) Highway Statistics 2014 - Policy | Federal Highway Administration. US Dep Transp Fed Highw Adm 2014.http://www.fhwa.dot.gov/policyinformation/statistics/2014 I. (Accessed 15.07.2018)

(24) Dunn LB. American Driving Survey: Methodology and Year 1 Results, May 2013- May 2014. Found Traffic Saf, p.2-3.(2015)

(25) Department for Transport UK. Road Traffic Estimates : Great Britain 2014. (2015).

(26) Australian motorists drive an average $15,530 \mathrm{~km}$ per year - Roy Morgan Research. Roy Morgan 2013. http://www.roymorgan.com/findings/australian-moterists-driveaverage-15530km-201305090702. (Accessed 15.07.2018)

(27) LTA. Singapore land transport statistics in brief 2014. L. Transp. Authority, Singapore 2 (2014).

(28) Huo, H., Zhang, Q., He, K., Yao, Z. \& Wang, M. Vehicle-use intensity in China: Current status and future trend. Energy Policy Vol.43, pp.6-16 (2012).

(29) Pearre, N. S., Kempton, W., Guensler, R. L. \& Elango, V. V. Electric vehicles: How much range is required for a day's driving? Transp. Res. Part C Emerg. Technol. Vol.19, pp.11711184 (2011).

(30) Naunheimer, H., Bertsche, B., Ryborz, J. \& Novak, W. in Automotive Transmissions SE - 2 28-72 (Springer Berlin Heidelberg, 2011). doi:10.1007/978-3-642-16214-5_2

(31) Hidrue MK, Parsons GR, Kempton W, Gardner MP. Willingness to pay for electric vehicles and their attributes. Resour Energy Econ, Vol.33, p.686-705.(2011) doi:10.1016/j.reseneeco.2011.02.002.

(32) Ruan J, Walker PD, Watterson PA, Zhang N. The dynamic performance and economic benefit of a blended braking system in a multi-speed battery electric vehicle. Appl Energy 2016;183:1240-58. doi:http://dx.doi.org/10.1016/j.apenergy.2016.09.057.

(Accessed 15.07.2018)

(33) Saxena, S., MacDonald, J. \& Moura, S. Charging ahead on the transition to electric vehicles with standard $120 \mathrm{~V}$ wall outlets. Appl. Energy Vol. 157, pp.720-728 (2014).

(34) Bi, Z., Song, L., De Kleine, R., Mi, C. C. \& Keoleian, G. A. Plug-in vs. wireless charging: life cycle energy and greenhouse gas emissions for an electric bus system. Appl. Energy, Vol.146, pp.11-19 (2015). 